\title{
Influence of grain size and mineralogy on the porosity/cement ratio
}

\author{
S. RIOS*, A. VIANA DA FONSECA*, N. C. CONSOLI†, M. FLOSS $\$$ and N. CRISTELO§
}

\begin{abstract}
The porosity/cement ratio is defined as the ratio between porosity and the volumetric cement content (volume of cement over the total volume) and it is often adjusted by an exponent ( $\xi$ ) to the volumetric cement content $\left(n / C_{\mathrm{iv}}^{\xi}\right)$, which seems to depend on the type of soil. This ratio is very useful to analyse artificially cemented soils and it depends on easily calculated moulding properties. Although there are already some results regarding the correlation of this ratio with the mechanical behaviour of different soils, a theory explaining the variation of the exponent $\xi$ has yet to be established. In this work, the influence of grain size and mineralogy on $\xi$ was pursued, considering them to be the most important factors. For that purpose, a soil was divided into three different fractions, whose grain size distribution and mineralogy were known, and the exponents obtained correlating the ratio with the maximum shear modulus or the unconfined compression strength were compared. The results show that the grain size distribution explains part of the $\xi$ variation, but mineralogy and particle shape seem to have the most decisive influence. This was even more evident when comparing two uniform sands.
\end{abstract}

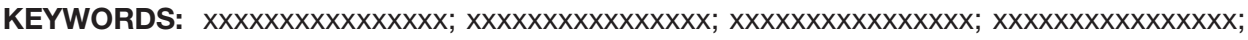

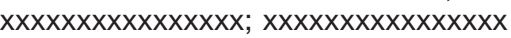

ICE Publishing: all rights reserved

\section{INTRODUCTION}

Artificially cemented soils are often used in the underlying layers of roads and railways as base or subgrade materials, especially when in situ soils do not have the required mechanical properties. Cement can significantly increase the strength and stiffness of these layers, contributing to a reduction in their degradation and consequently to lower maintenance costs and higher serviceability. The design parameters of these mixtures can be defined by correlating them with mixture conditions using an index ratio such as the ratio between porosity and the volumetric cement content $\left(n / C_{\text {iv }}\right)$. The volumetric cement content is calculated by the ratio of the volume of cement to the total volume of the specimen, expressed as a percentage. It is possible that the reactions involved in cement curing change the initial void ratio and, furthermore, it is difficult to know how much of the initial cement has actually built new bonding connections between particles. For this reason, it is simpler to use an index property that includes well-known parameters and which can represent a certain mixture. In fact, this ratio has proved to be very useful to predict the mechanical behaviour of artificially cemented soils, as has been demonstrated in terms of compression strength and stiffness (Consoli et al., 2012a), tensile strength (Consoli et al., 2011), stress-dilatancy (Consoli et al., 2012b), isotropic compression behaviour at high pressures (Rios et al., 2012), shearing behaviour (Rios et al., 2013) and fatigue tests (Viana da Fonseca et al., 2012a).

Manuscript received 8 January 2013; first decision 12 April 2013; accepted 24 July 2013.

Published online at www.geotechniqueletters.com on $X X$ Xxxxxxxxxx 2013.

* Department of Civil Engineering, Faculty of Engineering of the University of Porto, Porto, Portugal

$\dagger$ Department of Civil Engineering, Federal University of Rio Grande do Sul, Porto Alegre, Rio Grande do Sul, Brazil

* Department of Civil Engineering, University of Passo Fundo, Rio Grande do Sul, Brazil

$\S$ Department of Civil Engineering, University of Trás os Montes e Alto Douro, Vila Real, Portugal
In some of the above-mentioned works an exponent $(\xi)$ was included in the ratio, affecting the volumetric cement content $\left(n / C_{\mathrm{iv}}^{\xi}\right)$. Although it is almost certain that the value of $\xi$ depends on the soil type, it is not yet certain whether it depends mainly on grain size or on mineralogy, or both. In this paper, this issue is addressed using mixtures of Portland cement and a residual soil from granite, two different fractions of this soil and a uniform sand, which were tested for unconfined compression strength and seismic wave velocity.

\section{GRAIN SIZE DISTRIBUTION AND MINERALOGY}

The main soil used in this study was a remoulded residual soil from granite from the Porto region, Portugal, known as Porto silty sand. Two additional mixtures were also prepared using different fractions of this soil. The 'fine to coarse sand' fraction was obtained by removing the fines content, corresponding to the fraction passed on ASTM sieve no. $200(0.074 \mathrm{~mm})$. The fraction between ASTM sieves no. $40(0.425 \mathrm{~mm})$ and no. $200(0.074 \mathrm{~mm})$ yielded the 'fine sand' fraction. A fourth soil-cement mixture, a uniform sand known as Osorio sand, was also studied. In its natural conditions, Porto residual soil from granite has been widely studied in geotechnical and geological terms, as described by Viana da Fonseca (2003) and Viana da Fonseca et al. (2006). It originates from granite, a leucocratic medium grain size rock with sparse megacrystals, the rock being isotropic without any foliation. The main minerals are quartz, feldspars such as microcline, anorthoclase, oligoclase and albite, and micas (mainly muscovite and rare biotite).

Mineralogical analysis of the residual soil and its resulting fractions was performed at the microscopy unit of the University of Trás os Montes e Alto Douro using Xray diffraction, with the aim of determining the proportions of the most important minerals (quartz, kaoline and micas) in each of them. It should be noted that the composition of residual soils depends on their weathering degree. In this case, since feldspars from the parent rock 
turn into kaoline after weathering, it is more important to know the amount of kaoline in the soil. To improve the reliability of the results, $200 \mathrm{~g}$ of each of the three soils obtained by quartering were milled and then reduced again to a small amount by successive quartering. This preliminary preparation was necessary since the representativeness of very small samples quartered from soils with large grain sizes is not acceptable, unless the larger grains are included in the collected sample, which can only happen if they are thoroughly milled. The results presented in Table 1 show that the amount of quartz and micas are the most relevant. Micas are predominant $(51 \%)$ in the fine sand fraction, while quartz is the most significant in the other two soils $(53 \%$ and $60 \%$ respectively for the fine to coarse sand fraction and Porto silty sand). In fact, the presence of micas in the fine sand fraction was clearly seen at first sight (Fig. 1), which might have a significant influence on soil behaviour.

Osorio sand is a non-plastic uniform fine sand obtained from the region of Osorio, near Porto Alegre, in southern Brazil. According to Consoli et al. (2012a), mineralogical analysis of this soil showed that the sand particles are predominantly quartz.

The grain size distribution of the soils considered in this study is shown in Fig. 2, while their physical parameters are assembled in Table $2 ; D_{10}, D_{30}, D_{50}$ and $D_{60}$ allowed calculation of the coefficients of uniformity $\left(C_{\mathrm{u}}\right)$ and curvature $\left(C_{\mathrm{c}}\right)$. The values of solid particle density $G$ are also given in the table, together with the soil classification according to ASTM (1998).

\section{PREPARATION OF SPECIMENS FOR MECHANICAL TESTS}

Several specimens were prepared by mixing soil, water and Portland cement in different proportions. Their characteristics are summarised in Table 3 in terms of cement content $(C)$, initial void ratio $\left(e_{0}\right)$ and water content $(w)$. At least two specimens were prepared under the same moulding conditions to ensure reproducibility of the tests.

The soil-cement mixture was worked until it reached a uniform consistency and then it was subjected to static compaction in three layers in a stainless steel lubricated mould of $70 \mathrm{~mm}$ diameter and $140 \mathrm{~mm}$ height (see Consoli et al., 2011). The mixing and compaction procedures took less than $30 \mathrm{~min}$, so that the curing process was not significantly affected by them. To reduce the curing time and therefore the duration of the experimental programme, a high-strength Portland cement was used (CEM 52.5R), which allowed a curing period of 7 days. For this reason, all specimens were tested at 7 days, with no significant gain in strength after this period (Rios et al., 2013).

According to Viana da Fonseca et al. (2012b) the compaction procedure would induce anisotropic behaviour in the tested specimens; however, since the same procedure was used for all the specimens this fact does not changes the conclusions expressed in this paper. Moreover, to obtain a degree of compaction similar to those observed in soilcement subgrades in road and railway lines (in this case with dry unit weights higher than $80 \%$ of the modified

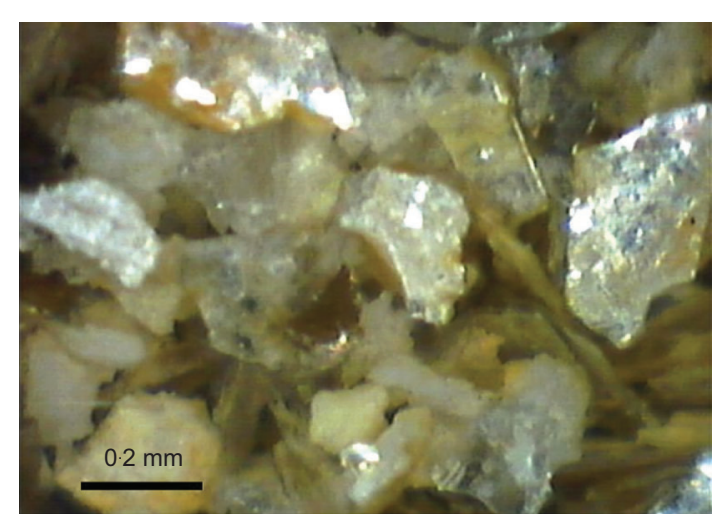

Fig. 1. Photograph of the fine sand fraction

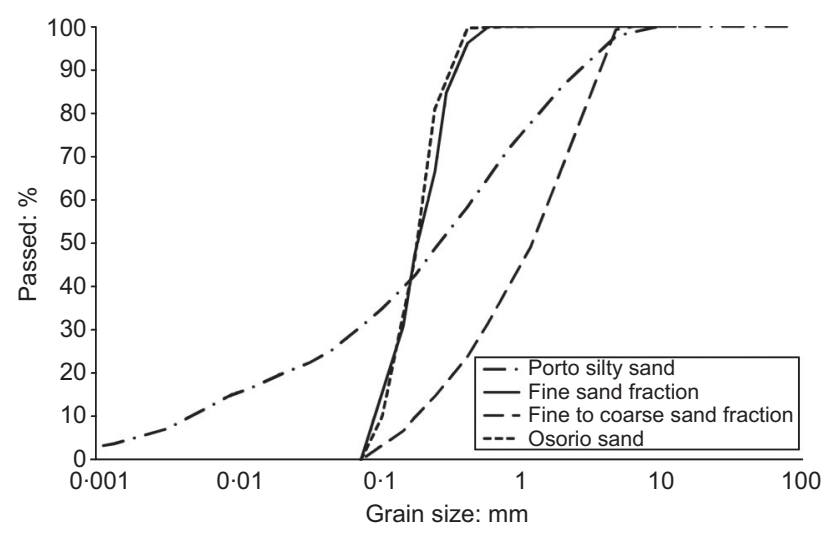

Fig. 2. Grain size distribution curves

Proctor test), significant compaction energy was needed and thus anisotropy was unavoidable.

\section{UNCONFINED COMPRESSION STRENGTH AND ELASTIC STIFFNESS \\ Procedures}

Shear wave velocity measurements (using bender elements) and unconfined compression tests were performed on the specimens listed in Table 3. The specimens were submerged in water $24 \mathrm{~h}$ prior to the test to improve saturation and minimise suction effects. To allow the introduction of the bender element into the specimen after the curing period, a small hole was made in the top and bottom of the specimen just after demoulding. Immediately before testing, the bender was introduced in the hole and the surrounding air volume was filled with a paste made with soil and water to improve coupling between the bender and the specimen. This procedure enhanced the accuracy of the measurements, which in this case were interpreted using the first arrival, therefore considering the time domain theory (Viana da Fonseca et al., 2009). Subsequently, elasticity theory was used to determine the relationship between shear wave velocity $V_{\mathrm{s}}$ and maximum shear modulus $G_{0}$

Table 1. Mineral fractions of each soil

\begin{tabular}{l|c|c|c}
\hline & Mica: $\%$ & Kaolinite: $\%$ & Quartz: \% \\
\hline Fine sand fraction & 51 & 11 & 38 \\
Fine to coarse sand fraction & 45 & 2 & 53 \\
Porto silty sand & 32 & 8 & 60 \\
\hline
\end{tabular}


Table 2. Physical parameters obtained for the three materials

\begin{tabular}{l|c|c|c|c}
\hline & Fine sand fraction & $\begin{array}{c}\text { Fine to coarse sand } \\
\text { fraction }\end{array}$ & Porto silty sand & Osorio sand $^{\mathrm{b}}$ \\
\hline$D_{10}: \mathrm{mm}$ & $0 \cdot 09$ & $0 \cdot 19$ & $0 \cdot 004$ & $0 \cdot 10$ \\
$D_{30}: \mathrm{mm}$ & $0 \cdot 15$ & $0 \cdot 55$ & $0 \cdot 070$ & $0 \cdot 15$ \\
$D_{50}: \mathrm{mm}$ & $0 \cdot 19$ & $1 \cdot 18$ & $0 \cdot 250$ & $0 \cdot 19$ \\
$D_{60}: \mathrm{mm}$ & $0 \cdot 22$ & $1 \cdot 70$ & $0 \cdot 450$ & $0 \cdot 20$ \\
$C_{\mathrm{c}}$ & $1 \cdot 14$ & $0 \cdot 94$ & $2 \cdot 720$ & $1 \cdot 20$ \\
$C_{\mathrm{u}}$ & $2 \cdot 44$ & $8 \cdot 95$ & $112 \cdot 500$ & $1 \cdot 90$ \\
$G$ & $2 \cdot 63$ & $2 \cdot 66$ & $2 \cdot 720$ & $2 \cdot 63$ \\
USCS $^{\mathrm{a}}$ & SP, poorly graded sand & SP, poorly graded sand & SM, silty sand & SP, poorly graded sand \\
\hline
\end{tabular}

${ }^{\mathrm{a}}$ Unified soil classification system (ASTM, 1998)

${ }^{\mathrm{b}}$ From Consoli et al. (2012a)

$$
G_{0}=\rho V_{\mathrm{s}}^{2}
$$

where $\rho$ is the specimen density.

The unconfined compression strength $\left(q_{\mathrm{u}}\right)$ was obtained by performing tests at $1.14 \mathrm{~mm} / \mathrm{min}$ in an automatic loading machine with a $100 \mathrm{kN}$ load cell.

\section{Results}

The obtained values of the maximum shear modulus and unconfined compression strength were analysed by the porosity/cement ratio $\left(n / C_{\mathrm{iv}}^{\xi}\right)$ defined earlier. In order to express the contribution of the different parameters to $C_{\mathrm{iv}}$, the following equation was used

$$
C_{\mathrm{iv}}=\frac{C \gamma_{\mathrm{d}}}{(1+C) \gamma_{\mathrm{s}}} \times 100
$$

in which $C$ is the cement content, $\gamma_{\mathrm{d}}$ is the dry unit weight of the soil and $\gamma_{\mathrm{s}}$ is the cement particle unit weight, assumed to be $3 \cdot 1 \mathrm{~g} / \mathrm{cm}^{3}$. Equation (2) shows that $C_{\mathrm{iv}}$ is not only a dependent function of the cement content but also of the dry unit weight of the soil, which affects the overall volume of the mixture.

The exponent $\xi$ controls the contribution of the volumetric cement content to the strength or stiffness relatively to the porosity. According to previous results in other soils (Consoli et al., 2011), $\xi$ seems to be not greater than one, which means that density has a higher importance than cementation in the material behaviour. The different values of $\xi$ that have been experimentally determined up to the present date indicate that, in wellgraded soils, the contribution of porosity is more important than cement content, while for uniform sands both parameters seem to have a similar effect. This experimental evidence can be explained by the physical behaviour of sands - well-graded soils achieve lower $e_{\min }$ values and thus the density parameter has a stronger effect on their behaviour. On the contrary, uniform sands have a much lower $e_{\max }-e_{\min }$ range, meaning that the compaction degree is less significant.

The importance of the grain size on the value of $\xi$ seems to be understood, but the influence of the mineralogy or particle shape is yet to be found. In order to evaluate that correlation, the values of $G_{0}$ and $q_{\mathrm{u}}$ were plotted against $n / C_{\mathrm{iv}}^{\xi}$, separately for each soil, and the exponent that provided the best correlation coefficient in the power regression was determined. For both strength and stiffness, the best correlation was achieved using an exponent of $0 \cdot 10$ for the fine sand fraction, $1 \cdot 0$ for the fine to coarse sand fraction and $0 \cdot 21$ for Porto silty sand, the latter already having been reported by Rios et al. (2012) - see Fig. 3 and Fig. 4.

These values seem to be in agreement with the previous considerations: the well-graded Porto silty sand $\left(C_{\mathrm{u}}=\right.$ $112 \cdot 5)$ has a lower $\xi$ value while the fine to coarse sand fraction has an exponent of 1.0 since it is more poorly graded $\left(C_{\mathrm{u}}=8 \cdot 95\right)$. However, the fine sand fraction $\left(C_{\mathrm{u}}=\right.$ $2 \cdot 44$ ) presented an exponent of $0 \cdot 10$ - a value that can only be explained by the soil mineralogy, which in this case is also related to particle shape. In the fine sand fraction, the predominant minerals are the micas, which - having a lamellar shape - provide higher values of the void ratio, extending the influence of density in the mechanical behaviour of the soil. From these results it can be

\begin{tabular}{|c|c|c|c|c|c|}
\hline & $C: \%$ & $e_{0}$ & $w: \%$ & $n$ & $C_{\mathrm{iv}}$ \\
\hline Fine sand fraction & $\begin{array}{l}2 \text { and } 5 \\
2 \text { and } 5 \\
2 \text { and } 5\end{array}$ & $\begin{array}{l}1 \cdot 30 \\
1 \cdot 50 \\
1 \cdot 70\end{array}$ & 10 & $\begin{array}{l}57 \\
60 \\
63\end{array}$ & $\begin{array}{l}0 \cdot 70-1 \cdot 73 \\
0 \cdot 65-1 \cdot 60 \\
0 \cdot 60-1 \cdot 48\end{array}$ \\
\hline $\begin{array}{l}\text { Fine to coarse sand } \\
\text { fraction }\end{array}$ & $\begin{array}{l}2,3,5 \text { and } 7 \\
2,3,5 \text { and } 7 \\
2,3,5 \text { and } 7 \\
2,3,5 \text { and } 7\end{array}$ & $\begin{array}{l}0 \cdot 82 \\
0 \cdot 69 \\
0 \cdot 62 \\
0 \cdot 58\end{array}$ & 12 & $\begin{array}{l}45 \\
41 \\
38 \\
37\end{array}$ & $\begin{array}{l}0 \cdot 92-3 \cdot 05 \\
0 \cdot 97-3 \cdot 32 \\
1 \cdot 02-3 \cdot 44 \\
1 \cdot 06-3 \cdot 56\end{array}$ \\
\hline Porto silty sand & $\begin{array}{l}2,3,5 \text { and } 7 \\
2,3,5 \text { and } 7 \\
2,3,5 \text { and } 7 \\
2,3,5 \text { and } 7\end{array}$ & $\begin{array}{l}0 \cdot 64 \\
0 \cdot 56 \\
0 \cdot 50 \\
0 \cdot 42\end{array}$ & 12 & $\begin{array}{l}39 \\
36 \\
33 \\
30\end{array}$ & $\begin{array}{l}1 \cdot 05-3 \cdot 53 \\
1 \cdot 10-3 \cdot 70 \\
1 \cdot 15-3 \cdot 80 \\
1 \cdot 18-3 \cdot 97\end{array}$ \\
\hline Osorio sand ${ }^{\mathrm{a}}$ & $\begin{array}{l}2,3,5 \text { and } 7 \\
2,3,5 \text { and } 7 \\
2,3,5 \text { and } 7\end{array}$ & $\begin{array}{l}0 \cdot 62 \\
0 \cdot 70 \\
0 \cdot 80\end{array}$ & 10 & $\begin{array}{l}38 \\
41 \\
44\end{array}$ & $\begin{array}{l}1 \cdot 05-3 \cdot 49 \\
1 \cdot 00-3 \cdot 34 \\
0 \cdot 94-3 \cdot 14\end{array}$ \\
\hline
\end{tabular}

Table 3. Moulding characteristics of the specimens

${ }^{\mathrm{a}}$ From Consoli et al. (2012a) 


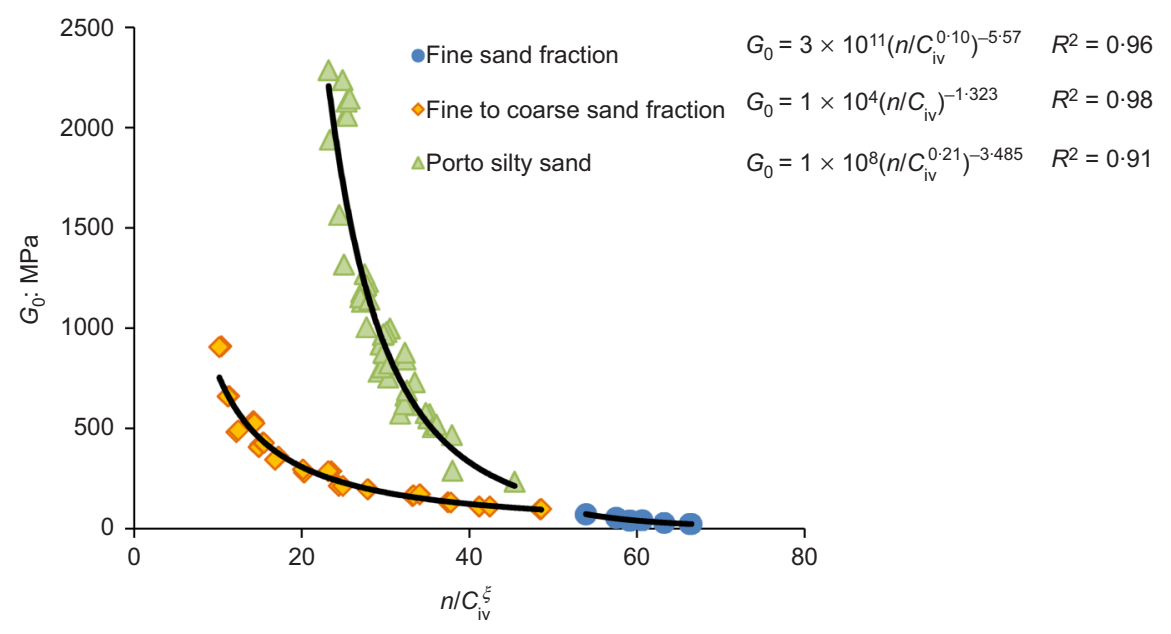

Fig. 3. Maximum shear modulus plotted against adjusted porosity/cement ratio with different $\xi$ exponents to the volumetric cement content

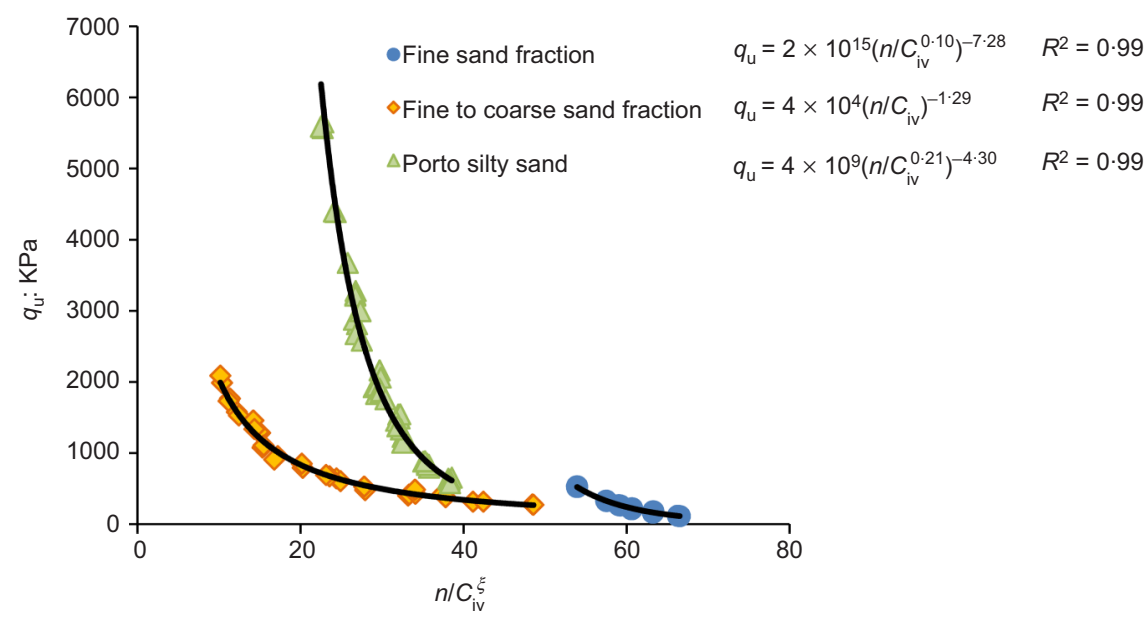

Fig. 4. Unconfined compression strength plotted against adjusted porosity/cement ratio with different $\xi$ exponents to the volumetric cement content

concluded that for soils with similar mineralogy, the grain size distribution is the most relevant factor. However, for soils with very different minerals in their composition, resulting in different particle shapes, the mineralogy (related to particle shape) is the decisive factor.

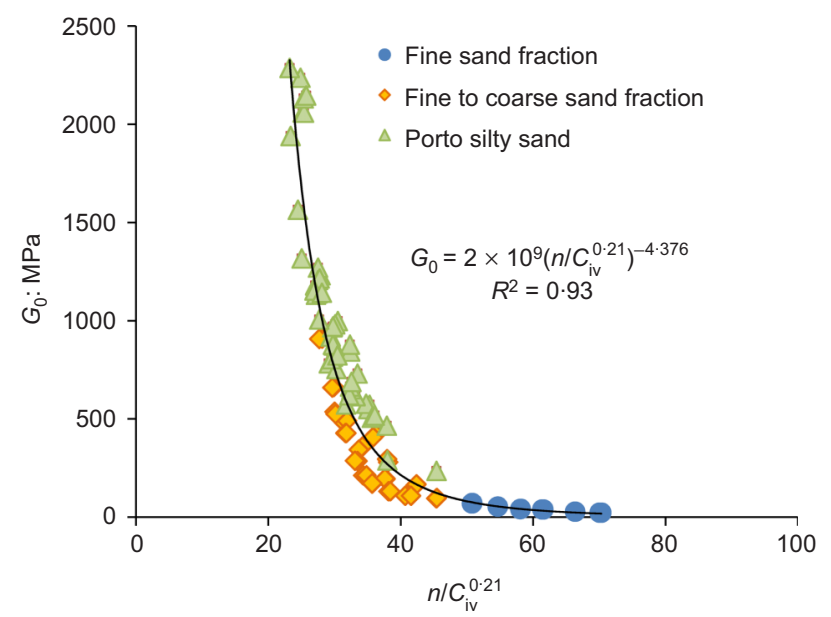

Fig. 5. Maximum shear modulus plotted against adjusted porosity/cement ratio $(\xi=0 \cdot 21)$
To better understand this particular point, the three soils were plotted together with the same exponent of 0.21 obtained for the Porto silty sand, from where the two fractions were derived. Figures 5 and 6 show very interesting results since a unique power regression was obtained for the

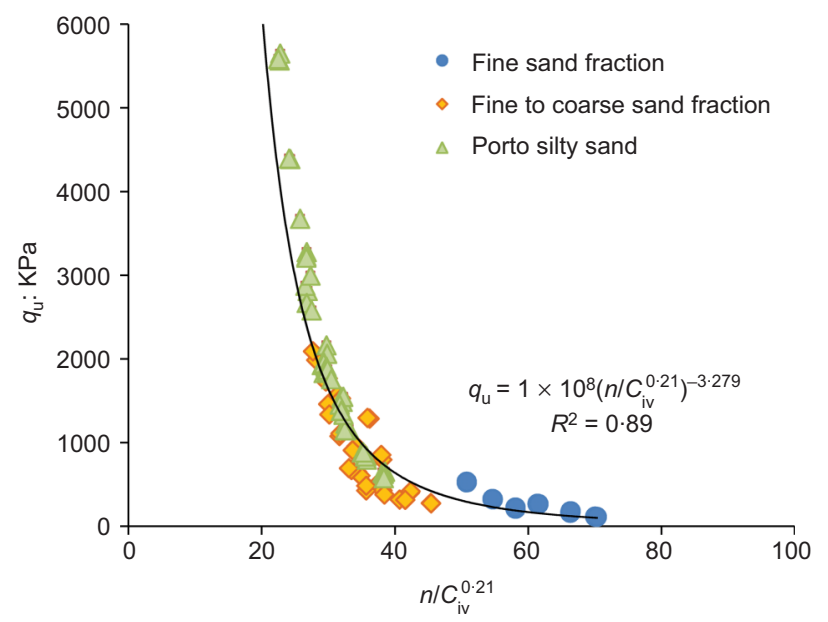

Fig. 6. Unconfined compression strength plotted against adjusted porosity/cement ratio $(\xi=0.21)$ 


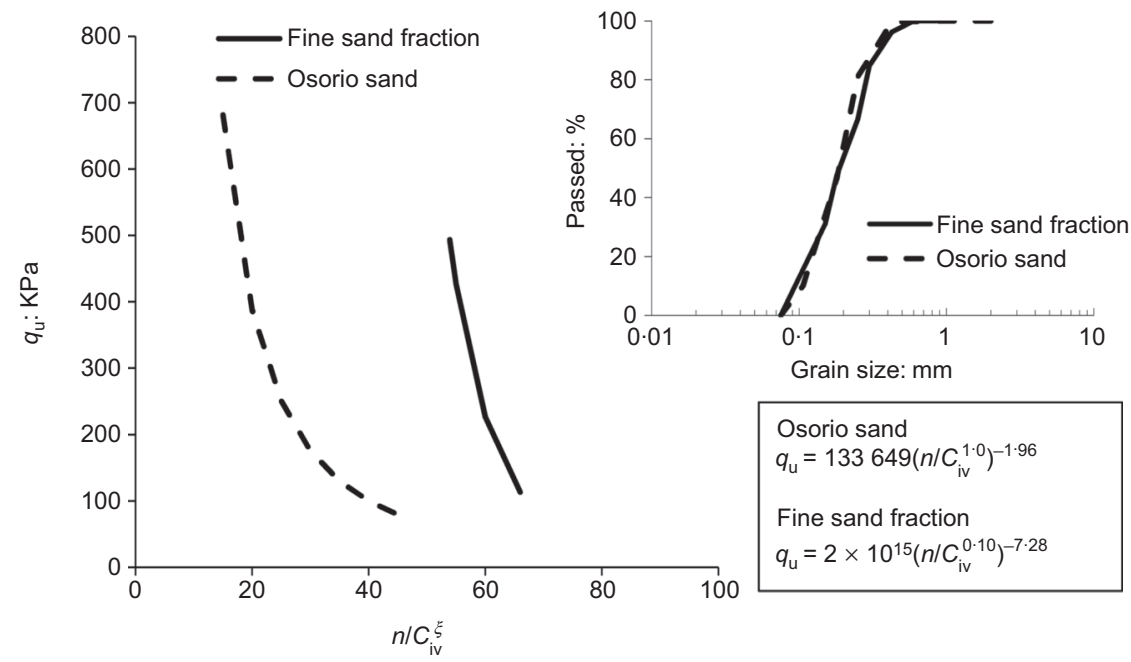

Fig. 7. Unconfined compression strength plotted against adjusted porosity/cement ratio for two uniform sands with different minerals and distinct exponents $\xi$

three soils, with a good correlation coefficient in both stiffness and strength. Taking into consideration the fact that the fine sand fraction has very small values of strength and stiffness, probably due to the amount of micas, this provides a good definition of the power regression near the $x$-axis asymptote. The fine to coarse sand fraction follows with higher strength/stiffness and, finally, the Porto silty sand presents points with the highest values. These results show that, despite the different grain size distributions, the three soils can be assembled together by one single exponent, characteristic of the minerals present in this soil.

Figures 7 and 8 show two uniform sands with different minerals but similar grain size distributions, comparing the fine sand fraction (composed mainly of micas) and Osorio sand (comprising quartz grains of rounded shape (Consoli et al., 2012b)). The results of unconfined compression strength and maximum shear modulus presented in this paper showed that the best exponent to the fine sand fraction is $0 \cdot 10$, while for Osorio sand it is $1 \cdot 0$ (Consoli et al., 2012a), despite their close grain size distribution curves. Again, this can be explained by their different mineralogies, which result in different particle shapes. For these two sands, a unique line with a single exponent was also plotted, as reported in Fig. 5 and Fig. 6 for Porto silty sand and their derived fractions. However, a $\xi$ value providing a unique line for both sands was not found, as shown in Fig. 9 and Fig. 10 for an exponent value of $1 \cdot 0$ since the curves are completely different. This is a consequence of the different minerals and particle shapes present in both soils. This is even clearer with the use of two simple examples.

- For an initial void ratio of $1 \cdot 0$ (which corresponds to $50 \%$ porosity), to have $600 \mathrm{kPa}$ of unconfined compression strength, cement contents of $6 \cdot 77 \%$ and $1 \cdot 24 \%$ are needed for the Osorio sand and the fine sand fraction respectively, corresponding to $C_{\mathrm{iv}}$ values of $3 \cdot 14 \%\left(n / C_{\mathrm{iv}}\right.$ $=15 \cdot 8)$ and $0.61 \%\left(n / C_{\mathrm{iv}}^{0 \cdot 1}=52 \cdot 5\right)$ respectively. The stiffness values obtained for both sands are also considerably different $-1141 \mathrm{MPa}$ for Osorio sand and $79 \mathrm{MPa}$ for the fine sand fraction.

- On the other hand, to have an unconfined compression strength of $400 \mathrm{kPa}$ with $5 \%$ cement content, very different initial void ratios were needed: 0.78 for Osorio sand and 1.41 for the fine sand fraction. This corresponds to index ratios equal to $n / C_{\mathrm{iv}}=19 \cdot 4$ and $n / C_{\mathrm{iv}}^{0 \cdot 1}=55 \cdot 5$ respectively, which leads to maximum

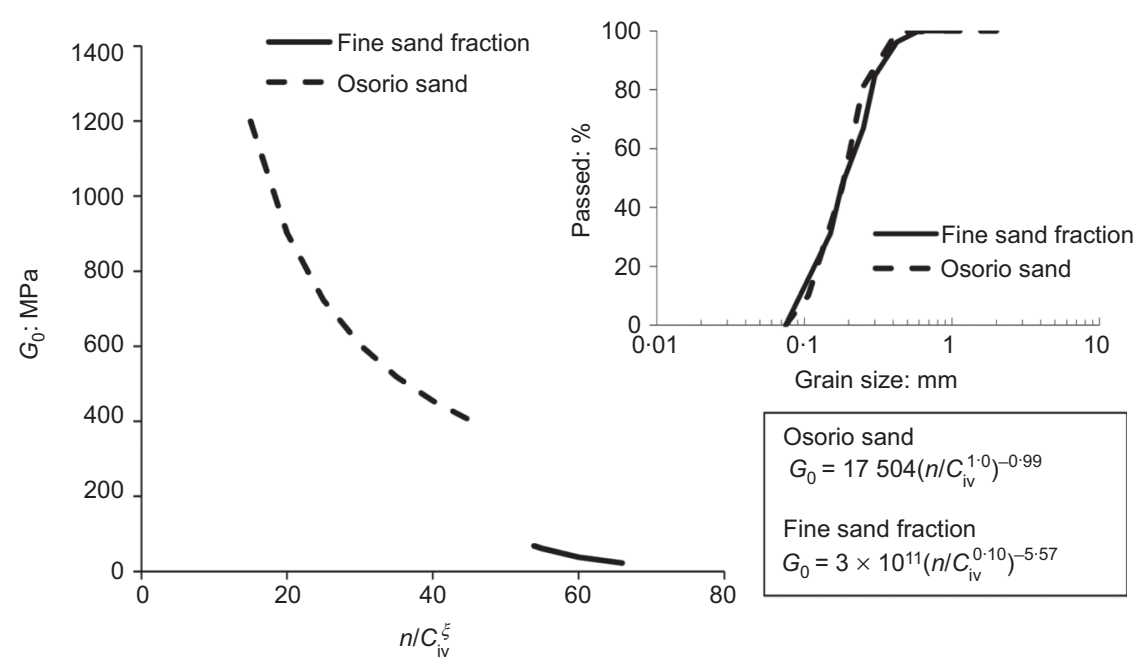

Fig. 8. Maximum shear modulus plotted against adjusted porosity/cement ratio for two uniform sands with different minerals and distinct exponents $\xi$ 


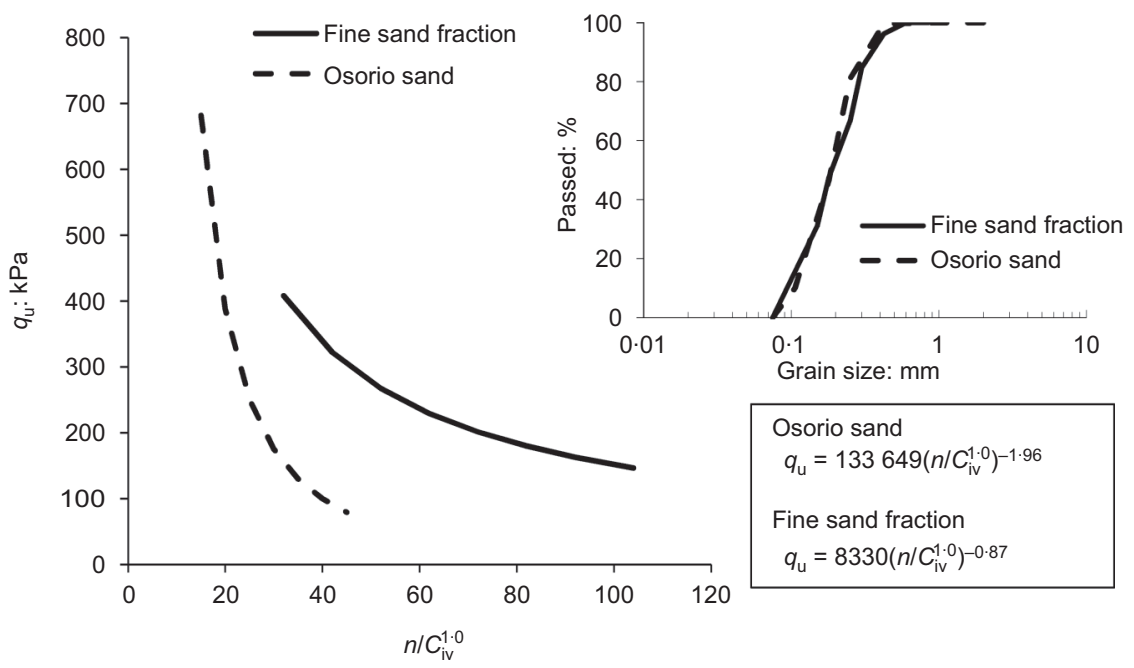

Fig. 9. Unconfined compression strength plotted against adjusted porosity/cement ratio for two uniform sands with different minerals and the same exponent $(\xi=1 \cdot 0)$

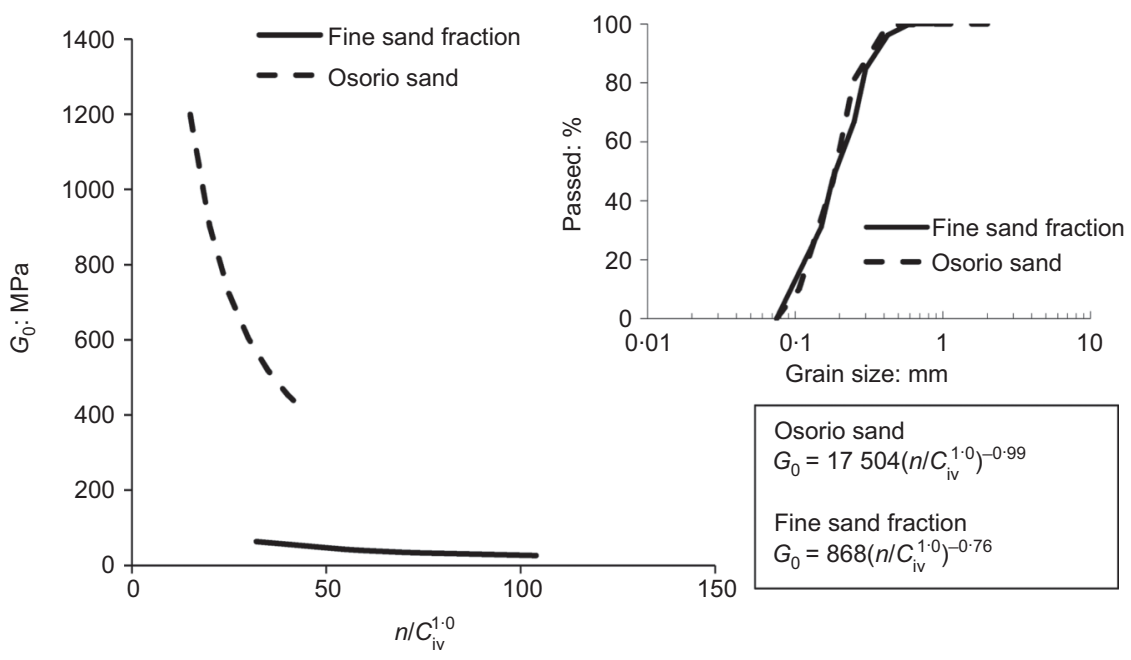

Fig. 10. Maximum shear modulus plotted against adjusted porosity/cement ratio for two uniform sands with different minerals and the same exponent $(\xi=1 \cdot 0)$

shear modulus $\left(G_{0}\right)$ values of $930 \mathrm{MPa}$ for Osorio sand and $58 \mathrm{MPa}$ for the fine sand fraction.

Considering these results, it is clear that the value of the exponent $\xi$ plays a major role since it reflects the greater or lesser contribution of porosity or cement content to stiffness and strength. The two examples presented show that, due to the distinct exponent values - a consequence of the minerals present in the soils - the cement content or void ratio needed to achieve certain strength is quite different for the two sands.

\section{CONCLUSIONS}

This paper highlights the influence of grain size and mineral composition on the exponent $\xi$ of the porosity/cement ratio $n / C_{\mathrm{iv}}^{\xi}$. To make this index property really simple to use, it is very important to know how this exponent changes. Working with a well-graded silty sand and some fractions from this soil, this paper revealed that, to some extent, grain size distribution may have a certain effect: better graded soils with wider grain size distribution curves have lower exponent values than poorly graded soils. However, soil mineralogy and particle shape may have a decisive higher influence on this factor, being more important than grain size in the soils analysed in this work. This was even more evident when comparing two uniform sands (Osorio sand and the fine sand fraction) that have distinct $\xi$ values $(1 \cdot 0$ and $0 \cdot 1$, respectively) due to their different mineral compositions (quartz for Osorio sand and micas for the fine sand fraction).

As the value of $\xi$ is mainly related to the soil mineralogy or particle shape, instead of trying to correlate this exponent with grain size parameters such as $D_{50}$, other parameters (e.g. angularity) need to be taken into account. These conclusions, although limited to the soils studied here, are very important for the development of this research study so that quantitative analysis can be carried out - that is, definition of a specific correlation between the value of the exponent $\xi$ and quantified soil parameters.

\section{REFERENCES}

ASTM (1998). D 2487-98: Standard practice for classification of soils and engineering purposes. ASTM, West Conshohocken, PA, USA.

Consoli, N. C., Viana da Fonseca, A., Cruz, R. \& Rios, S. (2011). Voids/cement ratio controlling tensile strength of cement 
treated soils. J. Geotechn. Geoenviron. Engng 137, No. 11, 1126-1131, http://dx.doi.org/10.1061/(ASCE)GT.1943-5606. 0000524.

Consoli, N. C., Viana da Fonseca, A., Rios, S., Cruz, R. \& Fonini, A. (2012a). Parameters controlling stiffness and strength of artificially cemented soils. Géotechnique 62, No. 2, 177-183, http://dx.doi.org/10.1680/geot.8.P.084.

Consoli, N. C., Cruz, R. C., Viana da Fonseca, A. \& Coop, M. (2012b). Influence of the voids-cement ratio on stressdilatancy-strength behavior of artificially cemented sand. $J$. Geotechn. Geoenviron. Engng 138, No. 1, 100-109.

Rios, S., Viana da Fonseca, A. \& Baudet, B. (2012). The effect of the porosity/cement ratio on the compression behavior of cemented soil. J. Geotechn. Geoenviron. Engng 138, No. 11, 1422-1426, http://dx.doi.org/10.1061/(ASCE)GT.1943-5606. 0000698.

Rios, S., Viana da Fonseca, A. \& Baudet, B. (2013). The effect of the porosity/cement ratio on the shearing behaviour of cemented soil. Acta Geotech. accepted for publication.
Viana da Fonseca, A. (2003). Characterizing and deriving 3 engineering properties of a saprolitic soil from granite, in Porto. In Characterization and engineering properties of natural soils (Tan et al. (eds)). Lisse: Swets and Zeitlinger, pp. 13411378.

Viana da Fonseca, A., Carvalho, J., Ferreira, C., et al. (2006). Characterization of a profile of residual soil from granite combining geological, geophysical and mechanical testing techniques. Geotech. Geol. Engng 24, No. X, 1307-1348.

Viana da Fonseca, A., Ferreira, C. \& Fahey, M. (2009). A framework interpreting bender element tests, combining timedomain and frequency-domain methods. Geotech. Test. J. 32, No. 2, 1-17.

Viana da Fonseca, A., Rios, S., Amaral, M. F. \& Panico, F. (2012a) Fatigue cyclic tests on artificially cemented soil. Geotech. Test. J. 36, No. 2, 1-10, http://dx.doi.org/10.1520/GTJ20120113.

Viana da Fonseca, A., Rios, S. \& Amaral, M. F. (2012b). Structural anisotropy by static compaction. Engng Geol., http://dx.doi.org/10.1016/j.enggeo.2012.11.012.

\section{WHAT DO YOU THINK?}

To discuss this paper, please email up to 500 words to the editor at journals@ice.org.uk. Your contribution will be forwarded to the author(s) for a reply and, if considered appropriate by the editorial panel, will be published as a discussion. 


\section{Author Queries}

Journal: Géotechnique Letters-

Paper title: Influence of grain size and mineralogy on the porosity/cement ratio

Dear Author

During the preparation of your manuscript for publication, the questions listed below have arisen. Please mark your amends directly on the pdf as per the instructions in your proof notification email. Many thanks for your assistance

\begin{tabular}{|l|l|l|}
\hline $\begin{array}{l}\text { Query } \\
\text { Reference }\end{array}$ & Query \\
\hline 1 & $\begin{array}{l}\text { Please choose up to } 6 \text { suitable } \\
\text { keywords from http://www.icevir- } \\
\text { tuallibrary.com/upload/geotechni- } \\
\text { quekeywords.pdf }\end{array}$ & \\
\hline 2 & $\begin{array}{l}\text { Any publication details (volume, } \\
\text { issue, page numbers) yet? }\end{array}$ & \\
\hline 3 & Please give editor's initials & \\
\hline 4 & Please give issue number. & \\
\hline 5 & $\begin{array}{l}\text { Is value of } 112 \cdot 500 \text { for Cu of } \\
\text { Porto sand OK? }\end{array}$ & \\
\hline
\end{tabular}

